\title{
Mechanisms of Somatostatin Action in RINm5F Cells in Culture: Preliminary Evidence for Possible Altered G Protein Function ${ }^{1}$
}

\author{
Michael K. McLeod, M.D., Piyush Kothary, M.S., Mark Wari氵ock, B.S., \\ Atsuschi Fukuuchi, M.D., and Angela M. Tutera, B.S. \\ Department of Surgery, University of Michigan Medical Center, Section of General Surgery-Division \\ of Endocrine Surgery, Ann Arbor, Michigan 48109-0331
}

Submitted for publication November 25, 1991

Octreotide (SMS), a somatostatin analogue, is an established antigrowth peptide, but it does not effectively inhibit the growth of insulinoma cells. In order to study the mechanisms that underlie this apparent lack of an antiproliferative effect on insulinoma tumor cells we established the rat insulinoma cell line, RINm5F, in culture. Cells in culture were tested by incubation in media with and without SMS. To study tritiated $\left[{ }^{3} \mathbf{H}\right]-$ thymidine incorporation into extracted DNA (TTID), 2 $\mu \mathrm{Ci} /$ well of ${ }^{3} \mathrm{H}$ was added for $24 \mathrm{hr}$, and cells were harvested and assayed for TTID (cpm/ $\mu \mathrm{g}$ DNA). Insulin (IRI) and intracellular cAMP (cAMP ${ }_{i}$ were measured by RIA. To study the effects of SMS on insulin secretion, conditioned media were sampled after $24 \mathrm{hr}$. To study the effects of $\mathbf{C A M P}_{i}$, conditioned medium was used to extract $\mathrm{CAMP}$, following incubation with SMS for $15 \mathrm{~min}$. Increasing concentrations of SMS had no significant effect on TTID in the presence of $1 \%$ FBS. Trypan bluc cxclusion tests showed $>90 \%$ viable cells throughout all stages of these experiments. There were no significant differences in cell numbers and protein content in the presence of SMS. There was a significant decrease in the secretion of insulin and intracellular cAMP levels in response to $50 \mathrm{n} M$ SMS. However, SMS significantly inhibited TTID in RINm5F cells following a 4-hr pretreatment with pertussis toxin (PT) $(23553 \pm 1747$ vs $20635[\mathrm{cpm} / \mu \mathrm{g}$ DNA] \pm 1983 [SEM], $\boldsymbol{P}<0.01$ ). We conclude that the inhibition of insulin secretion by SMS is associated with an attenuation of cAMP formation. However, the effects of SMS on cell proliferation appear to be distinct and more complex. The unexpected ability of PT to induce the inhibition of TTID by SMS suggests that SMS mediates, at least some of, its effects on cell proliferation in RINm5F cells via a possibly altered $G$ protein or related signal transducing mechanism. Further study of the signal transduction system in RINm5F cells may elucidate the mech-

\footnotetext{
${ }^{1}$ Presented at the Annual Meeting of the Association for Academic Surgery, Colorado Springs, CO, November 20-23, 1991.
}

anisms of tumor growth in insulinoma. (c) 1992 Academic Press, Inc.

\section{INTRODUCTION}

Somatostatin, a cyclic tetradecapeptide initially isolated from ovine hypothalamus as an inhibitor of growth hormone release, has been localized in many other tissues [1]. It is a well-established antisecretory and antiproliferative peptide. Sandostatin (octreotide, SMS 201-995, Sandoz Pharmaceutical Co., East Hanover, $\mathrm{NJ}$ ) is a long-acting, octapeptide analogue of somatostatin. It, similarly, has demonstrated antiproliferative effects (both in vivo and in vitro) on a variety of solid tumors including breast [2], prostate [3, 4], colon [5], pancreatic [6], and small-cell lung carcinoma [7], as well as, other clonal tumor cells $[8,9]$. Also, it has been shown to inhibit pcptide secretion in patients with functioning endocrine tumors [10-12]. However, octreotide (SMS) does not effectively inhibit the growth of cells in insulinomas, despite it being a well-established antigrowth peptide.

Transmembrane signal (hormone, growth factor, etc.) receptors are associated with a class of proteins bound to the cytoplasmic side of the cell membrane which bind to guanine nucleotides such as guanosine triphosphate (GTP) with high affinity [13]. These membrane-bound cytoplasmic guanine nucleotide-binding proteins, called $\mathrm{G}$ proteins $[14,15]$, are linked to protein synthesis $[13$, 16] and are believed to play a role in controlling cell proliferation and growth [17].

Somatostatin is known to act via an inhibitory guanine nucleotide binding protein $\left(G_{i}\right)$ in many cell systems [18-25]. The absence of any demonstrable somatostatin-induced antiproliferative effect on insulinoma cells suggests that there may be either an altered or a different guanine nucleotide subunit protein, or a related transduction mechanism in insulinomas. To study this further, we established the rat insulinoma cell line, 
RINm5F, in culture to use as a model for human insulinoma. The RINm5F cell line was originally established from an X-ray induced rat insulinoma [26] and has been shown to store and release immunoreactive insulin [27]. The release of insulin from RINm5F cells is stimulated by a variety of secretagogues (amino acids and triose glyceraldehyde), but not by glucose [28, 29].

\section{METHODS}

RINm5F cells were maintained in $75-\mathrm{cm}^{2}$ tissue culture flasks at $37^{\circ} \mathrm{C}$ in $5 \% \mathrm{CO}_{2}$ in Roswell Park Memorial Institute 1640 culture media (RPMI-1640) supplemented with $5 \%$ heat-inactivated fetal bovine serum, 2 $\mathrm{m} M$ L-glutamine, $1 \%$ penicillin, and $1 \%$ streptomycin and were allowed to grow to confluence before beginning each experimental protocol. In preparation for each experiment, cells were detached using $0.05 \%$ trypsin$0.53 \% \mathrm{~m} M$ NaEDTA in Hank's balanced salt solution and subsequently were plated onto 5 wells in 6 -well tissue culture plates and grown in $2 \mathrm{ml}$ medium supplemented with $1 \%$ fetal bovine serum $\times 48 \mathrm{hr}$. This was followed by $2 \mathrm{ml}$ of standard media (RPMI-1640 with 2 $\mathrm{m} M$ L-glutamine, $1 \%$ penicillin, and $1 \%$ streptomycin) supplemented with $0.5 \%$ fetal bovine serum $\times 24 \mathrm{hr}$. The medium was aspirated and $2 \mathrm{ml}$ fresh medium was added at the start of all test conditions. The viability of cells was tested by trypan blue exclusion tests. These tests showed $>90 \%$ viable cells throughout all stages of these experiments.

\section{Treatment with Pertussis Toxin}

RINm5F cells were pretreated with pertussis toxin (PT) $(100 \mathrm{ng} / \mathrm{ml})$ for $4 \mathrm{hr}$. Studies in which RINm5F cells were preincubated with concentrations of PT ranging from 50 to $400 \mathrm{ng} / \mathrm{ml}$ produced results that were similar to those obtained with $100 \mathrm{ng} / \mathrm{ml}$ for a 4 -hr pretreatment. The wells containing PT were aspirated, replaced with $2 \mathrm{ml}$ medium, and the respective additive dosages of octreotide were used for each test condition.

\section{Treatment with Octreotide (SMS 201-995)}

Cells were incubated with octreotide $(50,500$, or 5000 $\mathrm{nM}) \times 16 \mathrm{hr}$ prior to a 24 -hr pulse with tritiated thymidine. Previous experiments have demonstrated that throughout a range of $5 \times 10^{-4} M$ to $10^{-15} M$ octreotide 50 and $500 \mathrm{nM}$ most consistently produced the maximum responses in tritiated thymidine incorporation into extracted DNA [30].

\section{Tritiated Thymidine Uptake}

Following a 16-hr incubation, $2 \mu \mathrm{Ci} /$ well $\left[\right.$ methyl $\left.{ }^{3} \mathrm{H}\right]$ thymidine (Amersham) was added to cells. RINm5F cells were incubated for $24 \mathrm{hr}$, then washed with cold phosphate-buffered saline. Two milliliters of $6 \%$ trichlo- roacetic acid was added to each well, and cells were scraped and rinsed from tissue culture plates. Cell fragments were centrifuged $\times 2$ at $1800 \mathrm{rpm}$ for $20 \mathrm{~min}$. The supernatant was used to measure the protein content and counts in a scintillation counter. The cell pellet was treated with $3 \%$ perchloric acid (PCA), heated at $95^{\circ} \mathrm{C}$ for $10 \mathrm{~min}$, iced for $20 \mathrm{~min}$, and then centrifuged at 2900 rpm for $10 \mathrm{~min}$. Supernatant was used to measure DNA by direct assay.

\section{DNA Assay}

Two hundred and fifty microliters of $3 \%$ perchloric acid was added to assay tubes. DNA standard was prepared using $0.3 \mathrm{mg} / \mathrm{ml}$ DNA (calf thymus, Sigma) in 5 $\mathrm{mM} \mathrm{NaOH}$ diluted 1:1 in $1 \mathrm{~N}$ perchloric acid, heated to $70^{\circ} \mathrm{C}$ for $15 \mathrm{~min}$.

A DNA standard curve was used to estimate unknown values. One milliliter of diphenylamine reagent was added to a total volume of 500- $\mu$ l samples and incubated at $30^{\circ} \mathrm{C}$ for $6-24 \mathrm{hr}$. Samples were read at $600 \mathrm{~nm}$ on a spectrophotometer (Hitachi, Model 100-40). Results for tritiated thymidine incorporation into extracted DNA were calculated and expressed as counts per minute per microgram of DNA.

\section{Insulin}

To study the effects of octreotide on insulin secretion, conditioned media were sampled after $24 \mathrm{hr}$ with and without octreotide. Replicates $\times 5$ were used in each experiment. Results are expressed as mean \pm SEM $(N \geqslant 3)$.

Immunoreactive insulin was measured by using a double-antibody radioimmunoassay with an ${ }^{125}$ I-porcine insulin tracer, a rat insulin standard (Novo), a guinea pig anti-rat insulin first antibody (Linco Research), and a sheep anti-guinea pig gamma globulin-PEG second antibody. Limit of sensitivity for the assay was $3 \mu \mathrm{U} / \mathrm{ml}$. Interassay and intraassay coefficients of variability were 3.2 and $1.4 \%$, respectively.

\section{Cyclic Adenosine Monophosphate (cAMP)}

Intracellular cAMP was measured following incubation with octreotide for $15 \mathrm{~min}$. Cold 6\% TCA (1 ml) was added to wells, and cells were scraped off using a rubber policeman. Fragments and TCA were collected and placed into tubes ( 5 wells/tube) and centrifuged at 1800 rpm for $20 \mathrm{~min}$. The supernatant was washed in $4 \times 4 \mathrm{ml}$ with diethyl ether (saturated with water), and $200 \mathrm{ml}$ from the aqueous layer was assayed for immunoreactive cAMP.

A double-antibody radioimmunoassay using an ${ }^{125} \mathrm{I}$ tracer (New England Nuclear), a rabbit anti-cAMP first antibody (Vaitukatis, Boston City Hospital), and a sheep anti-rabbit IgG second antibody was applied. The sample and standards are acetylated prior to assaying 


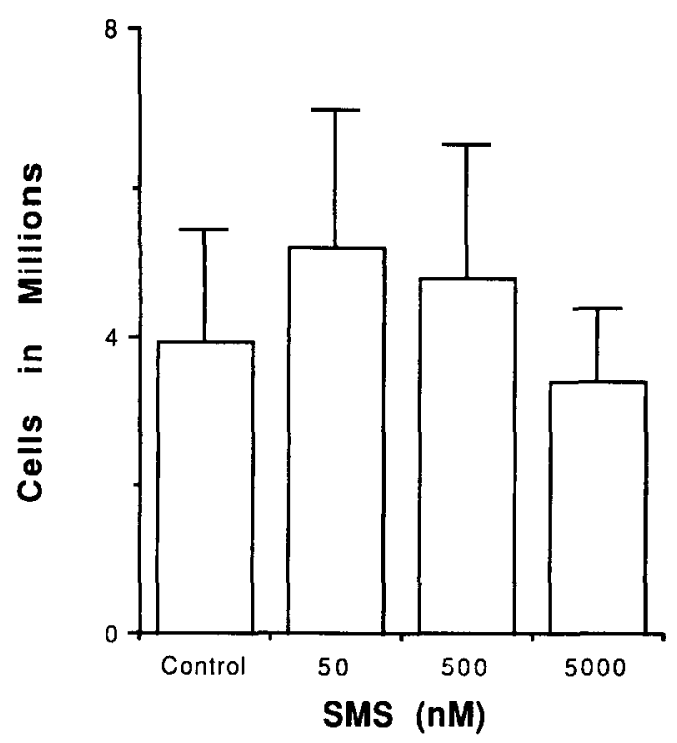

FIG. 1. The response of cell number in RINm5F cells to various doses of octreotide (SMS). RINm5F cells $\left(10^{6}\right)$ were plated and grown as described under Methods. The media was then aspirated. Cells were then incubated in test media containing $1 \%$ fetal bovine serum for 24 hr. Cells were then scraped and viable cells as determined by trypan blue exclusion rest were counted using hemocytometer. The data are representative of five experiments. The vertical lines represent \pm SEM. For experimental details, see Methods.

for greater sensitivity. Limit of sensitivity is $17.8 \mathrm{fmole} /$ $\mathrm{ml}$. Interassay and intraassay coefficients of variability are 5.4 and $1.5 \%$, respectively.

\section{Statistics}

Significant differences between treatment groups were tested for using the Wilcoxon rank sign test and the Student $t$ test. A $P$ value $\leqslant 0.05$ was the criterion used to identify a significant difference.

\section{RESULTS}

\section{Effect of Octreotide on Cell Number and Tritiated Thymidine Incorporation}

A number of studies have shown that somatostatin or one of its analogues (SMS) inhibit cell proliferation [7-

TABLE 1

\section{Effect of Octreotide (SMS) on Protein Content}

\begin{tabular}{cc} 
Test conditions (Reagents) & $\begin{array}{c}\text { Protein content }(\mu \mathrm{g}) \\
(n=5)\end{array}$ \\
\hline Control & $108 \pm 5$ \\
$50 \mathrm{n} M$ SMS & $102 \pm 5$ \\
$500 \mathrm{n} M$ SMS & $110 \pm 3$ \\
$5000 \mathrm{n} M$ SMS & $120 \pm 7$ \\
\hline
\end{tabular}

Note. Protein content was measured by the Lowry method [42]. See Methods for details. Data are expressed as the mean \pm SEM from triplicate determinations from five experiments.

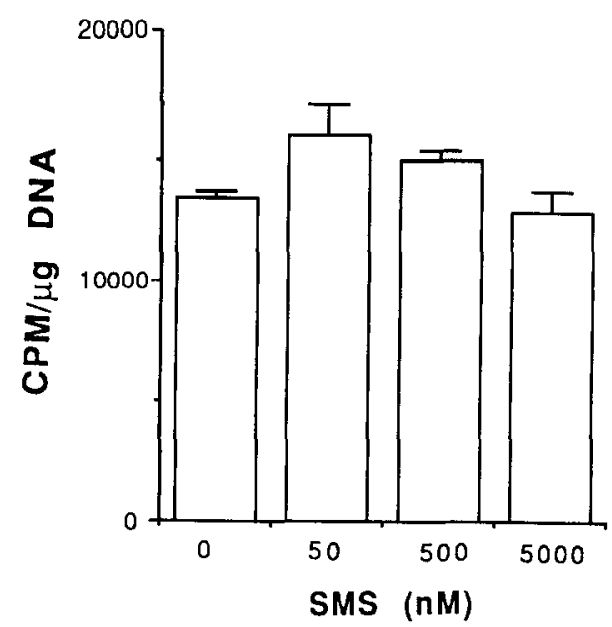

FIG. 2. The effect of various doses of octreotide (SMS) on tritiated thymidine incorporation into extracted DNA from RINm5F cells as indicated by $\mathrm{cpm} / \mu \mathrm{g}$ DNA on the ordinate-axis. The data are representative of three or more experiments. The vertical lines represent \pm SEM. For experimental details, see Methods, and Figure 1.

$9,23]$. In contrast to these studies, there was no significant inhibition in cell numbers with increasing concentrations of octreotide $(50-5000 \mathrm{nM})$ in the RINm5F cell (shown in Fig. 1). Similarly, there were no significant changes in protein content observed in RINm5F cells incubated in the presence of the same range of dosages of octreotide (Table 1).

To further study the observed lack of effect of octreotide on RINm5F cell number, we examined the effect of octreotide on tritiated thymidine incorporation into the extracted DNA of these cells. Increasing concentrations of octreotide (50-5000 $\mathrm{nM}$ ) had no significant effect on the extent of tritiated thymidine incorporation into extracted DNA (TTID) in RINm5F cells incubated in the presence of standard media supplemented with $1 \%$ fetal bovine serum (shown in Fig. 2).

\section{Effect of Octreotide on Insulin Secretion and Intracellular Cyclic AMP}

Insulin secretion (IRI) and intracellular cyclic AMP levels were significantly decreased in RINm5F cells

TABLE 2

Effect of Octreotide (SMS) on Insulin Secretion and Intracellular Cyclic AMP Formation

\begin{tabular}{lrr}
\hline \multicolumn{1}{c}{ Assay } & \multicolumn{1}{c}{ Control } & \multicolumn{1}{c}{ SMS 50 nM } \\
\hline Insulin $(\mu \mathrm{U} / \mathrm{ml})$ & $159 \pm 18$ & $129 \pm 15^{*}$ \\
Cyclic AMP $(\mathrm{fmole} / \mathrm{ml})$ & $1233 \pm 213$ & $1053 \pm 180^{*}$ \\
\hline
\end{tabular}

Note. Insulin and cyclic AMP were measured by insulin-specific and cyclic AMP-specific RIAs, respectively. For details see Methods. Data are expressed as the mean \pm SEM of 9-12 determinations from three or more experiments.

${ }^{*} P<0.05$ from control by Wilcoxon signed rank test. 


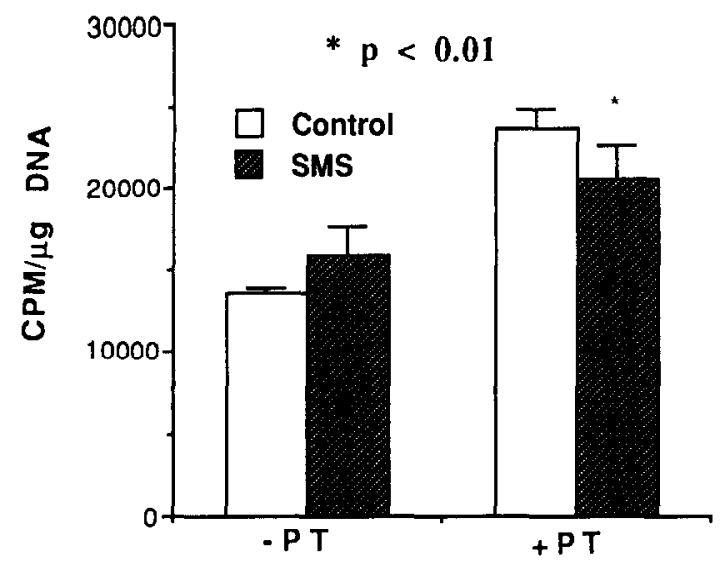

FIG. 3. The response of tritiated thymidine incorporation into extracted DNA (cpm/ $\mu$ g DNA) in RINm5F cells incubated in standard media $+1 \%$ fetal bovine serum either alone (control media/control) or in control media supplemented with $50 \mathrm{nM}$ octreotide (SMS). Both conditions were subjected to either a 4 -hr pretreatment with pertussis toxin $(100 \mathrm{ng} / \mathrm{mL})[+\mathrm{PT}]$ or a $4-\mathrm{hr}$ pretreatment without pertussis toxin $[-\mathrm{PT}]$. The data are representative of three or more experiments. The vertical lines represent \pm SEM. For experimental details, see Methods.

grown under previously described experimental conditions in response to SMS $(50 \mathrm{nM})$ (see Table 2).

\section{Effect of Octreotide on TTID after Pretreatment with Pertussis Toxin}

Pretreatment with pertussis toxin is known to disrupt the inhibitory alpha subunit of the guanine nucleotidebinding regulatory component $\left(\mathrm{G}_{\mathrm{i}}\right)$ by ADP-ribosylation and thereby block the inhibitory effect of SMS on the adenylate cyclase system. In these experiments, octreotide alone did not inhibit tritiated thymidine incorporation into extracted DNA; however, octreotide significantly inhibited tritiated thymidine incorporation into extracted DNA in RINm5F cells pretreated with pertussis toxin $(100 \mathrm{ng} / \mathrm{ml} / 4 \mathrm{hr})(23553 \pm 1747 \mathrm{vs} 20635[\mathrm{cpm} /$ $\mu \mathrm{g}$ DNA] \pm 1983 [SEM], $P<0.01$ ) (shown in Fig. 3). Similar results were observed even after pretreatment with $400 \mathrm{ng} / \mathrm{ml} / 4 \mathrm{hr}$ of pertussis toxin (data not shown). In addition, octreotide also inhibited insulin secretion into condition media from $47 \pm 4.0$ to $40 \pm 4.2(\mu \mathrm{U} / \mathrm{ml} \pm$ $\mathrm{SEM}$ ) in RINm5F cells pretreated with $50 \mathrm{ng} / \mathrm{ml}$ of pertussis toxin.

\section{DISCUSSION}

Somatostatin or its analogue is known to be a potent antisecretory and antigrowth peptide [31]. However, the exact mechanism(s) for its antigrowth effects are unknown. There are several fundamental mechanisms by which cell growth in endocrine cells may become abnormal. These mechanisms include abnormalities of growth factor production, abnormalities of growth factor receptors, reduced production of growth-inhibitory regulatory factors, or disturbances of post-receptor signal transduction [32]. Somatostatin may play a role in one or more of these fundamental mechanisms controlling abnormal (neoplastic) growth in any given cell.

Somatostatin was initially isolated based on its ability to inhibit growth hormone secretion from rat anterior pituitary cells in culture [1]. Subsequently, it has been shown to inhibit the secretion of several other hormones by pituitary cells in culture [33]. Furthermore, it has been shown that somatostatin inhibits such hormonal secretion by attenuating the formation of intracellular cyclic AMP [34, 35]. Our data demonstrating that octreotide inhibits insulin secretion and intracellular cyclic AMP levels in RINm5F cells are consistent with these reported observations.

Human studies using octreotide in the treatment of patients with malignant insulinomas have shown that octreotide does not reduce the size or inhibit the growth of the tumor, but that it does reduce the levels of circulating insulin (IRI) in such patients [36-38]. Our in vitro studies using a rat insulinoma cell line, RINm5F, also showed that increasing concentrations of octreotide did not reduce or inhibit the proliferation of cells, but it did reduce the levels of immunoreactive insulin secreted into the conditioned media (see Figs. 1 and 2, Table 2). In addition, we did not observe any significant changes in the protein content of these cells following treatment with octreotide. The parallel patterns of response of RINm5F cells in culture to those observed for human insulinumas suggest that our experimental model using RINm5F cells in vitro is a functional and useful model with which to investigate the mechanisms of peptide action in insulinomas.

Pertussis toxin is known to ADP-ribosylate the inhibitory alpha subunit of the membrane-bound guanine nucleotide binding protein, $\mathrm{G}_{\mathrm{i}}$. Somatostatin is known to mediate several of its postreceptor effects via the membrane-bound inhibitory subunit of guanine nucleotide binding protein $\left(\mathrm{G}_{\mathrm{i}}\right)$. Furthermore, it has been shown that the inhibitory effects of somatostatin can be blocked by pretreatment with pertussis toxin $[18,23$, $24,39]$.

In these experiments, pertussis toxin pretreatment followed by treatment with octreotide resulted in a significant inhibition of tritiated thymidine incorporation into the extracted DNA of RINm5F cells. The mechanism for this net inhibitory effect of octreotide in RINm5F cells only after pretreatment with pertussis toxin is unclear. It is possible that octreotide exerts both stimulatory and inhibitory effects on cell proliferation in RINm5F cells and that the stimulatory effects are pertussis toxin-sensitive. Alternatively, $\mathrm{G}_{\mathrm{i}}$ in the RINm5F cell may be altered, expressed differently, or associated with an abnormal or a different signal transducting mechanism in these cells. Consequently, pertussis toxin may exert a net activation of $G_{i}$ in the RINm5F cell.

Alteration of $G_{i}$ in disease states is not without prece- 
dent; for example, it has been shown that in patients with non-insulin-dependent diabetes, $\mathrm{G}_{\mathrm{i}}$ expression is altered [40]. The fact that pretreatment of RINm5F cells with pertussis toxin did not significantly alter (block) the inhibitory action of octreotide on insulin secretion (data described under Results) further supports the possibility that $G_{i}$ may be altered or expressed differently in RINm5F cells. The observation that pretreatment of RINm5F cells with pertussis toxin significantly altered the response of tritiated thymidine incorporation into DNA in these experiments further highlights the probability that the mechanisms mediating peptide secretion may be distinct from those mechanisms mediating cell proliferation. Recently reported findings on the existence of several distinct clones of somatostatin receptors in several tissues with apparent distinct cell effectors are consistent with this probability [41].

In conclusion, we have established a viable model to study the mechanisms of action of somatostatin in insulinomas. We have shown that there appears to be two distinct mechanisms of action of somatostatin in RINm5F cells. It appears that octreotide exerts its inhibitory action on peptide secretion by inhibiting or attenuating cyclic AMP formation, whereas its antiproliferative action appears to be related to either the net activation of $G_{i}$, or via an altered or different $G$ protein mechanism. Peptide receptors regulate the adenylyl cyclase system and related cell effector systems via $G$ proteins, as well as second messenger systems that include cyclic AMP. Further study of the signal transduction system in RINm5F cells may elucidate the apparently distinct mechanisms of peptide secretion and tumor cell proliferation in insulinoma.

\section{REFERENCES}

1. Brazeau, P., Vale, W., Burgus, R., Ling, N., Butcher, M., Rivier, J., and Guillemin, R. Hypothalamic polypeptide that inhibits the secretion of immunoreactive pituitary growth hormone. Science 179: 77,1973

2. Rose, D. P., Gottardis, M., and Noonan, J. J. Rat mammary carcinoma regressions during suppression of serum growth hormone and prolactin. Anticancer Res. 3: 323, 1983.

3. Schally, A. V., Comaru-Schally, A. M., and Redding, T. W. Antitumor effects of analogs of hypothalamic hormones in endocrinedependent cancers. Proc. Soc. Exp. Biol. Med. 175: 259, 1984.

4. Murphy, W. A., Lance, V. A., Moreau, S., Moreau, J-P, and Coy, D. H. Inhibition of rat prostate tumor growth by an octapeptide analog of somatostatin. Life Sci. 40: 2515, 1987.

5. Smith, J. P., and Solomon, T. E. Effects of gastrin, proglumide, and somatostatin on growth of human colon cancer. Gastroenterology 95: 1541, 1988.

6. Upp, J. R. Jr, Olson, D., Poston, G. J., Alexander, R. W., Townsend, C. M. Jr, and Thompson, J. C. Inhibition of growth of two human pancreatic adenocarcinomas in vivo by somatostatin analog SMS 201-995. Am. J. Surg. 155: 29, 1988.

7. Taylor, J. E., Bogden, A. E., Moreau, J-P, et al. In vitro and in vivo inhibition of human small cell lung carcinoma (NCI-H69) growth by a somatostatin analogue. Biochem. Biophys. Res. Commun. 153: 81, 1988.
8. Viguerie, N., Tahiri-Jouti, N., Ayral, A. M., Cambillau, C., Scemama, J. L., Bastie, M. J., Knuhtsen, S., Esteve, J. P., Pradayrol, L., Susini, C., and Vaysse, N. Direct inhibitory effects of a somatostatin analog, SMS 201-995, on AR4-2J cell proliferation via pertussis toxin-sensitive guanosine triphosphate-binding protein-independent mechanism. Endocrinology 124: 1017, 1989.

9. Pelicci, G., Pagliacci, M. C., Lanfrancone, L., Pelicci, P. G., Grignani, F., and Nicoletti, I. Inhibitory effect of the somatostatin analog octreotide on rat pituitary tumor cell (GH3) proliferation in vitro. J. Endocrinol. Invest. 13: 657, 1990.

10. O'Dorisio, T. M., Osei, K., and Falko, J. M. Effects of somatostatin (SMS) analog (201-995) on gastrin releasing peptide (GRP) and pancreatic polypeptide (PP) during provocative testing in a benign insulinoma. Clin. Res. 33: 877A, 1985.

11. Osei, K., and O'Dorisio, T. M. Malignant insulinoma: Effects of a somatostatin analog (compound 201-995) on serum glucose, growth, and gastro-entero-pancreatic hormones. Ann. Intern. Med. 103: 223, 1985.

12. Delemarre-van De Waal, H. A., Veldkamp, E. J. M., and Schrander-Stumpel, C. T. R. M. Long-term treatment of an infant with nesidioblastosis using a somatostatin analogue. $N$. Engl. J. Med. 316: 222, 1987.

13. Hughes, S. M. Are guanine nucleotide binding proteins a distinct class of regulatory proteins? FEBS Lett. 164(1): 1, 1983.

14. Gilman, A. G. G proteins: Transducers of receptor-generated signals. Annu. Rev. Biochem. 56: 615, 1987.

15. Stryer, L, and Bourne, H. R. G proteins: A family of signal transducers. Annu. Rev. Cell Biol. 2: 391, 1986.

16. Spiegel, A. M., Gierschik, P., Levine, M. A., and Downs, R. W., Jr. Clinical implications of guanine nucleotide-binding proteins as receptor-effector couplers. N. Engl. J. Med. 312: 26, 1985.

17. Murayama, T., and Ui, M. Possible involvement of a GTP-binding protein, the substrate of islet-activating protein, in receptormediated signaling responsible for cell proliferation. J. Biol. Chem. 262: 12463, 1987.

18. Reisine, T., Zhang, Y. L., and Sekura, R. Pertussis toxin treatment blocks the inhibition of somatostatin and increases the stimulation by forskolin of cyclic AMP accumulation and adrenocorticotropin secretion from mouse anterior pituitary tumor cells. J. Pharmacol. Exp. Ther. 232: 275, 1985.

19. Yajima, Y., Akita, T., and Saito, T. Pertussis toxin blocks the inhibitory effects of somatostatin on cAMP-dependent vasoactive intestinal peptide and cAMP-independent thyrotropin releasing hormone-stimulated prolactin secretion of GH3 cells. $J$. Biol. Chem. 261 (6): 2684, 1986.

20. Jacobs, K. H., Aktories, D., and Schultz, G. A nucleotide regulatory site for somatostatin inhibition of adenylate cyclase in $\$ 49$ lymphoma cells. Nature 303: 177, 1983.

21. Batzri, S. Direct action of somatostatin on dispensed mucosal cells from guinea-pig stomach. Biochim. Biophy. Acta. 677: 521, 1981.

22. Soll, A. H., Amirian, D. A., Thomas, L. P., Reedy, T. J., and Elashoff, J. D. Gastrin receptors on isolated canine parietal cells. J. Clin. Invest. 73(5): 1434, 1984.

23. Kaper, S., Kothary, P. C., and Kokudo, N. Somatostatin-14 blocks the hepatotrophic effects of insulin in the rat. J. Surg. Res. 50(4): 386, 1991.

24. Park, J., Chiba, T., and Yamada, T. Mechanisms for direct inhibition of canine gastric parietal cells by somatostatin. J. Biol. Chem. 262(29): 14190, 1987.

25. Susini, C., Bailey, A., Szecowka, J., and Williams, J. A. Charactcrization of covalently cross-linked pancreatic somatostatin receptors. J. Biol. Chem. 261(35): 16738, 1984.

26. Gazdar, A. F., Chick, W. L., Oie, H. K., Sims, H. L., et al. Continu- 
ous, clonal, insulin- and somatostatin-secreting cell line established from a transplantable rat islet cell tumor. Proc. Natl. Acad. Sci. USA 77: 3519, 1980.

27. Oie, H. K., Gazdar, A. F., Minna, J. D., et al. Clonal analysis of insulin and somatostatin secretion and L-dopa decarboxylase expression by a rat islet cell tumor. Endocrinology 112: 1070, 1983.

28. Praz, G. A., Galban, P. A., Wollheim, P. A., et al. Regulation of immunoreactive-insulin release from a rat cell line (RINm5F). Biochem. J. 210: 345, 1983.

29. Halban, P. A., Praz, G. A., and Wollheim, C. B. Abnormal glucose metabolism accompanies failure of glucose to stimulate insulin release from a rat pancreatic cell line (RINm5F), Biochem. J. 212: 439, 1983.

30. McLeod, M. K., Fukuuchi, A., Warnock, M., Tutera, A. M., and Vinik, A. I. Stimulative effects of somatostatin analogue (octreotide) on cell proliferation in rat insulinoma, RINm5F, cells. Surg. Forum 42: 133, 1991

31. Schally, A. V. Oncological applications of somatostatin analogues. Cancer Res. 48: 6977, 1988.

32. Steel, C. M. Peptide regulatory factors and malignancy. Lancet 2(8653): 30, 1989 .

33. Dorflinger, L. J., and Schonbrunn, A. Somatostatin inhibits vasoactive intestinal peptide-stimulated cyclic adenosine monophosphate accumulation in GH pituitary cells. Endocrinology 113: 1541, 1983.

34. Schofield, J. G., Mira-Moser, F., Schorderet, M., and Orci, L. Somatostatin inhibition of rat growth hormone release in vitro in the presence of $\mathrm{BaCl}_{2}$ or 3-isobutyl-1-methylxanthine. FEBS Lett. 46: 171, 1974.

35. I Ieindel, J. J., Williams, E., Robison, G. A., and Strada, S. J.
Inhibition of GH1 rat pituitary tumor cell adenylyl cyclase activity by somatostatin. J. Cyclic Nucleotide Res. 4(6): 453, 1978.

36. Long, R. G., Barnes, A. J., Adrian, T. E., Mallinson, C. N., Brown, M. R., Vale, W., Rivier, J. E., Christofides, N. D., and Bloom, S. R. Suppression of pancreatic endocrine tumour secretion by long-acting somatostatin analogue. Lancet 2: 764, 1979

37. Kvols, L. K., Buck, M., Moertel, C. G., Schutt, A. J., Rubin, J., O'Connell, M. J., and Hahn, R. G. Treatment of metastatic islet cell carcinoma with a somatostatin analogue (SMS 201-995). Ann. Intern. Med. 107(2): 162, 1987.

38. Schrezenmeir, J., Plewe, G., Sturmer, W., Kahaly, G., Opperman, D., Krause, U., Del Pozo, F., Kasper, H., and Beyer, .J. Treatment of APUDomas with the long-acting somatostatin analog SMS 201-995 investigations of therapeutic use and digestive side effects. Scand. J. Gastroenterol. 21 (S119): 223, 1986.

39. Katada, T., Bokoch, G. M., Northup, J. K., Ui, M., and Gilman, A. G. The inhibitory guanine nucleotide-binding regulatory com ponent of adenylate cyclase. J. Biol. Chem. 259: 3568, 1984.

40. Livingstone, C., McLellan, A. R., McGregor, M. A., Wilson, A. Connell, J. M., Small, M., Milligan, G., Paterson, K. R., and Houslay, M. D. Altered G-protein expression and adenylate cyclase activity in platelets of non-insulin-dependent diabetic (NIDDM) male subjects. Biochim. Biophys. Acta 1096: 127, 1991.

41. Yamada, Y., Post, S. R., Wang, K., Tager, H. S., Bell, G. I., and Seino, S. Cloning and functional characterization of a family of human and mouse somalostatin receplors expressed in brain, gastrointestinal tract, and kidney. Proc. Natl. Acad. Sci. USA 89: 251, 1992

42. Lowry, O. H., Rosenbrough, N. J., Farr, A. L., and Randall, R. J. Protein measurement with the folin phenol reagent. J. Biol. Chem. 193: 265, 1951. 